\title{
OBITUARIES
}

Prof. W. B. R. King, O.B.E., F.R.S.

Prof. KING died on January 23, 1963, when he appeared to be recovering from an operation which had not been regarded as serious. All who knew his mental agility and physical energy at the age of seventy-three were shocked by his premature death.

Prof. King was a notable figure in British geology, through a combination of several circumstances. His researches were characterized by variety, for he was no narrow specialist, but throughout his life the stratigraphy of the Lower Palæozoic and the Ordovician in particular were a major interest and gavo rise to some of his most important papers. For this he was always ready to acknowledge the inspiration of his old teacher, Prof. J. E. Marr, and it was from the same source that he was given his introduction to the Pleistocene. $\mathrm{He}$ was deeply interested in the development and modification of drainage patterns, particularly in his native Yorkshire dales, and since the First World War had been recognized as an authority on hydrological geology. After the Second World War, following his participation in Pluto, the cross-channel oil pipeline project, he became deeply interested in submarine geology and published notable pioneer papers on the interpretation of the floor of the English Channel.

With such a research rocord, together with his outstanding ability as a teacher whether in the lecture room or in the field, it is not surprising that King achieved high aeademic honours. After graduating at Cambridge in 1912, he was on the Geological Survey, in part nominally, until 1920, and then returned to Cambridge under Marr. From 1931 until 1943 he was Yates-Goldsmid professor at University College, London, and then succeeded Prof. O. T. Jones in the Woodwardian chair at Cambridge, from which he retired in 1955 .

In the eyes of the geological world, Prof. King was linked, as no other man was, with the two World Wars. He served through the whole of the First World War, rendering notable service with the Royal Engineers in problems of water supply, mine-driving and the provision of constructional materials, and he was awarded the O.B.F. and twice mentioned in despatches. When the Second World War broke out, he was called up immediately and remained in uniform until 1943. Not only was he involved in the Dunkirk evacuation, when he was awarded the M.C. for gallantry, but he also played an important part in the early planning of the Normandy invasion. As geological adviser to the Army Council for several years after the War, he was responsible for establishing a pool of geologists within the Reserve of Officers.

King was president of the Yorkshire Geological Society during 1949-50, of Section C (Geology) of the British Association in 1951, and of the Geological Society of London during 1953-55. For five years he acted as secretary of the latter body and he also served on the Council of the Royal Society. Scientific honours were bestowed abundantly on him, and it must suffice merely to list them. He was a foreign correspondent of the Palæontological Society of India, the Geological Society of America and the Geological Society of France; he received the Gosselet Medal from the Societé Geologique du Nord, the Prestwich Medal from the Geological Society of France and the Murchison Medal from the Geological Society of London; and the Universities of Lille and Rennes conferred honorary doctorates on him.

King was deeply attached to his native Wensleydale. Ho was born there on November 12, 1889, with two and a half centuries of family association with the dale behind him, and throughout his professional life he retained a dwelling there. When he retired from the Woodwardian chair, he and his wife went to live permanently at Worton, in Wensleydale. To Mrs. King as much as to him should be credited the reputation for quiet, warm-hearted hospitality and generous help to students and friends which characterized him at Cambridge, London or his cottage at Worton. His wife and two daughters survive him.

F. W. SHOTTON

\section{Dr. F. M. Brewer, C.B.E.}

Dr. Frederick Mason Brewer, who died suddenly in Oxford on February 11, was born in London on September 12, 1902. He was oducated at Owen's School, and in 1920 won an Open Scholarship in Natural Scienco at Lincoln College, Oxford. His tutor there was Sidgwick and in 1924 he obtained a 'First'. In 1925 ho went as a Commonwealth Fund Fellow to Cornell University, where he worked under Prof. Dennis. This was an experience which he greatly enjoyed, and many of his chemical interests, such as that in the element germanium, stemmed from this period. It was there that he met his wife, who was also working in the United States. On returning to England in 1927 he became a lecturer at Reading, but he returned to Oxford in 1928 as a University demonstrator in chemistry. He joined the staff of the Old Chemistry Department, now the Inorganic Chemistry Laboratory, under Prof. Soddy. He remained in that Department for the next thirty-five years, being for the last fifteen years in charge of the laboratory. F. M. Brewer was a great champion of inorganic chemistry and of the laboratory in which he worked. In his early days he took a very active part in the practical teaching, and when, in 1934, he was appointed to be an examiner in the Final Honour School he startled the candidates by setting papers more genuinely inorganic than any for some years. He had a strong belief that chemists, whether graduates or undergraduates, should know how substances behaved and what thoy wore like. Because of this he earried out many experiments in his lectures showing the properties of the less-common elements. Only a few weeks before his death he gave a Christmas Lecture for children on "Colour" and delighted his young audience by performing a large number of colourful experiments.

Dr. Brewer had a keen interest in geochemical problems and conducted a number of spectrographic studies of trace elements in rocks and minerals. Before the War, he carried out some investigations of divalent germanium compounds and in recent years he extended his interests to include the chemistry of gallium and indium in their lower oxidation states. His research group has made a number of contributions to our knowledge of gallium (I) compounds, including co-ordination compounds of gallium (I) tetrahalogallates and their behaviour in nonaqueous solvents.

When F. M. Brewer took charge of the Inorganic Chemistry Laboratory, plans had already been proposed for the building of a new department, but it was during the period he was in charge that the new building was erected. He made great contributions to the planning of this and was responsible for holding the department together when its research activities were scattered over a wide area. During this time the number of students engaged on research in the department increased manyfold. This increase was achieved smoothly, thanks to the guiding hand of F. M. Brewer. He led a department which grew in stature while he was there and all who 